\title{
Virtual Delivery of Simulation Education to Undergraduate Medical Students During the COVID-19 Pandemic
}

Kay Wu BSc*1, Alex Chan MD*1, Avinash Pandey MD*1, Puru Panchal BHSc ${ }^{1}$, Maroof Khalid $\mathrm{MD}^{1}$, Sudarshan Bala MD ${ }^{1}$, Samveg Shah MD ${ }^{1}$, Matthew C. Miller MD MSc FRCPC ${ }^{1}$

${ }^{1}$ Michael G. DeGroote School of Medicine, McMaster University, Hamilton, Canada

*Co-first authors, equal contribution.

\begin{abstract}
Background: The COVID-19 pandemic has restricted in-person clinical training for medical students. Simulation-based teaching is a promising tool to introduce learners to the clinical environment. MacSim is a student-led simulation workshop for learners to develop clinical competencies. The objective of this study was to assess the impacts of MacSim and participants' perspectives regarding simulation-based teaching.

Methods: A comprehensive simulation, representative of a virtual care scenario, was delivered to 42 pre-clerkship medical students via video conferencing. In pairs, participants obtained histories and carried out management plans for simulated patients. Participants were surveyed and interviewed. Survey data were analyzed using the Wilcoxon signedranks test. Interview transcript data were thematically analyzed.

Results: Post-simulation, participants ( $\mathrm{n}=24)$ felt more prepared to make clinical decisions, collaborate, and communicate in a virtual setting. $92 \%$ of respondents agreed MacSim was a valuable learning experience and $96 \%$ agreed more simulation-based learning should be integrated into curricula. Emergent themes from interviews ( $n=12)$ included: 1) value of simulation fidelity, 2) value of physician feedback, and 3) effectiveness of MacSim in improving virtual clinical skills.

Conclusion: Simulation-based teaching is of importance and educational value to medical students. It may play an increasingly prevalent role in education as virtual care is likely to become more prevalent.
\end{abstract}

Keywords: Education, Medical, Undergraduate; Simulation Training; Students, Medical; Teaching; User-Computer Interface 
medRxiv preprint doi: https://doi.org/10.1101/2021.08.20.21262347; this version posted August 22, 2021. The copyright holder for this preprint

\section{Introduction}

To adhere to social distancing guidelines introduced by the COVID-19 pandemic, a large proportion of educational activities have migrated to e-learning programs, and clinical encounters to telehealth provision. ${ }^{1-3}$ Though these changes have provided benefits in allowing healthcare providers to continue providing care, its introduction brings new challenges to practitioners and learners as new dimensions and barriers are added to patient interaction. ${ }^{4,5}$ Though novel strategies have been adopted to adapt to these changes, the introduction of novel clinical practices nonetheless bring on new challenges to developing pre-clerks. ${ }^{4-7}$ A promising tool being used to introduce pre-clerk students into the virtual clinic environment is simulationbased teaching. Traditionally, simulation-based teaching has been used at all levels of medical education, providing students a risk-free environment to gain necessary competencies to be proficient in the clinical environment. ${ }^{8-12}$

Though there have been extensive studies examining the efficacy of simulation-based teaching in different settings, few studies have characterized the efficacy of simulation teaching as a tool for integrating medical students into the virtual clinic environment, and the inclusion of simulation-based teaching can often be sparse for junior learners. ${ }^{13}$ The present study sought to address this knowledge gap by investigating perspectives and potential changes in self-perceived competencies of medical students after a virtual simulation.

\section{Methods}

\section{Study Design}

This cross-sectional study consisted of two components centred around a simulation event. The simulation event consisting of a 30-minute session in which participants had 20 minutes with a simulated patient in a virtual clinic environment, followed by 10 minutes of feedback from a physician assessor. The study design included comparison of pre- and post-event survey data, as well as post-event interview to assess perspectives regarding simulation teaching and COVID19. ${ }^{14}$ The study was PIPEDA-compliant and exempted from ethics approval by the Hamilton Integrated Research Ethics Board due to it being a quality improvement project.

\section{Recruitment}

Advertising of the event was done internally via social media and e-mail at the host school to 
medRxiv preprint doi: https://doi.org/10.1101/2021.08.20.21262347; this version posted August 22, 2021. The copyright holder for this preprint (which was not certified by peer review) is the author/funder, who has granted medRxiv a license to display the preprint in perpetuity.

It is made available under a CC-BY-NC-ND 4.0 International license .

second year students two weeks prior to the event. No financial incentives were included, and forty-two attendees participated in the event.

\section{Survey and Interview Design}

An online survey was sent to the attendees prior to and directly after the event. Non-identifying demographic data were obtained. Four Likert scale items were used to gauge perception of preparedness for clinical duties in the virtual environment, including history taking, clinical decision making, working in a team, and communicating with patients, measured on a scale of 1 (not at all prepared) to 5 (very well prepared). Data on participant perceptions on simulation learning were additionally gathered via Likert scales ranging from 1 (strongly disagree) to 5 (strongly agree). Statements used in the study to gauge student perception on the value of simulation-based learning included items such as "This event was a valuable learning experience to further familiarize myself with virtual clinics", "More simulation-based learning should be integrated into the pre-clerkship curriculum", and "COVID-19 has significantly reduced my opportunities for learning in a clinical setting”.

After the event, one-on-one interviews were conducted and transcribed verbatim with 12 randomly selected participants by one of the authors. Interviews lasted 20-30 minutes, utilizing the Modified Simulation Effectiveness Tool (SET-M), a validated tool for evaluation of simulation exercises in both nursing and medical students. ${ }^{14}$

\section{Statistical Analysis}

Analysis was done using Statistical Package for the Social Sciences (SPSS) 26. The Wilcoxon Signed-Rank Test was used to compare survey responses obtained before and immediately after the event following testing for parametric assumptions. ${ }^{15-16}$ Likert scale data were compared between pre- and post-event surveys to determine if there was an immediate impact in selfperceived preparedness for integration into the virtual clinic environment.

\section{Qualitative Analysis}

Analysis of the interviews was performed according to the six-step process described by Braun and Clarke. ${ }^{17}$ Interview transcripts were independently coded by two authors. Transcript data and codes were then qualitatively analyzed by the team to reach a consensus on relevant themes and 
subthemes.

\section{Results}

\section{Comparison of Survey Data}

There were 28 (70\% response rate) and 24 responses (60\% response rate) for the surveys sent before and immediately after the survey, respectively. The average age of attendees was 23.3 years $(\mathrm{SD}=2.2)$. The post-event survey showed significantly higher scores of perception of preparedness for history taking in the virtual clinic environment [pre-event $\mathrm{Mdn}=4(\mathrm{SD}=0.63)$, post-event $\mathrm{Mdn}=4(\mathrm{SD}=0.48), \mathrm{Z}=2.13, p<0.05]$, preparedness in clinical decision making [pre-event $\mathrm{Mdn}=3(\mathrm{SD}=0.57)$, post-event $\mathrm{Mdn}=3(\mathrm{SD}=0.79), \mathrm{Z}=3.35, p=0.001]$, working in a team setting [pre-event $\mathrm{Mdn}=3(\mathrm{SD}=0.79)$, post-event $\mathrm{Mdn}=4(\mathrm{SD}=0.77), \mathrm{Z}=2.51, p$ $<.05$ ], and communicating to patients in a virtual clinic environment [pre-event $\mathrm{Mdn}=3(\mathrm{SD}=$ $0.80)$, post-event $\mathrm{Mdn}=4(\mathrm{SD}=0.69), \mathrm{Z}=2.17, p<.05]$. Furthermore, participants agreed that the event was a valuable experience for their learning (Mean $=4.29, \mathrm{SD}=0.62$ ), strongly agreed that more simulation-based learning should be integrated into the pre-clerkship curriculum (Mean $=4.58, \mathrm{SD}=0.58)$, and strongly agreed that COVID-19 has significantly reduced their opportunities for learning in a clinical environment $($ Mean $=4.83, \mathrm{SD}=0.48)$. Results are summarized in Figure 1.

\section{Analysis of Interview Data}

Five major thematic categories emerged from the qualitative analysis (Table 1).

The "Collaboration and Communication" theme reflected the value of the exercise for learning how to work with a partner to make clinical decisions, for discussing and evaluating ideas, and for practicing case presentations.

The "Simulation Fidelity" theme revealed the value of simulation that was reflective of reality. One participant commented on the relatively less stressful nature of the simulation compared to a real case.

According to most participants, the simulation was effective for gaining practice for conducting histories and physical examinations virtually. Some participants commented on the challenges of conversing about decision-making through an online format in the presence of the standardized patient. 
medRxiv preprint doi: https://doi.org/10.1101/2021.08.20.21262347; this version posted August 22, 2021. The copyright holder for this preprint

Multiple participants identified that the simulation exercise helped with knowledge and skill development and identified feedback sessions with adjudicators to be particularly useful. Most participants stated that they would be in favor of integration of such simulation exercises into the pre-clerkship curriculum. Participants identified that it would be useful at multiple timepoints for knowledge integration and confidence-building prior to the start of clinical rotations.

\section{Discussion}

There is a paucity of information that examines the effectiveness of simulation-based teaching in the virtual clinical setting, and how attitudes toward simulation-based teaching may have changed during the COVID-19 pandemic.

Comparison of Likert Scale data from pre- and post-event surveys indicated statistically significant differences suggesting that participants felt significantly more prepared in all areas of history taking, working in a team, communicating with patients, and making clinical decisions. Though few studies have directly compared pre- and post-intervention data, this is in opposition to a prior study that found no differences in observable clinical outcomes when comparing the pre- and post-intervention groups after one extended simulation session, possibly demonstrating a discrepancy for when subjective and objective differences occur post-intervention. ${ }^{18}$

In our study, thematic analysis of interview questions showed similar themes to published qualitative analyses of medical simulation. A 2006 study of clerkship students interacting with robot simulators noted that high-fidelity simulation made students "feel [they] are interacting with a live patient"18(p217). This study also noted a theme, "suggestions for use and place in undergrad medical education", where as much as $22 \%$ of participants suggested more frequent and mandatory simulations in clerkship. ${ }^{18}$ During the COVID-19 pandemic, where virtual encounters are becoming the norm for outpatient visits, participants in our study were also noted to frequently compliment the fidelity of our simulation and request more frequent and mandatory virtual simulations in pre-clerkship. Several other studies have also noted themes of knowledge and skill development with simulation learning. ${ }^{19}$ A 2020 mixed-methods study of simulated scenario teaching run by peers also commented extensively on the value of peer feedback and observing peers participating in simulated encounters. ${ }^{19}$ It was noted that in review of the literature, previous studies with either quantitative or qualitative analysis of simulation of virtual 
medRxiv preprint doi: https://doi.org/10.1101/2021.08.20.21262347; this version posted August 22, 2021. The copyright holder for this preprint (which was not certified by peer review) is the author/funder, who has granted medRxiv a license to display the preprint in perpetuity.

It is made available under a CC-BY-NC-ND 4.0 International license .

interviews was not found.

Several limitations are recognized for the present study. Sampling bias and nonresponse bias may have factored into the survey data of the present study as participants involved in the study were solely composed of participants in the simulation event. A lack of a validated survey for data collection, and a small sample size may additionally impact the validity of findings.

\section{Conclusion}

To our knowledge, this study is the first mixed-methods evaluation of a student-run virtual care simulation for undergraduate medical students in the COVID-19 era. Data from our study provides new evidence to suggest that simulation-based learning may be a promising tool for improving student competencies in the virtual clinical setting. With further validation, these findings may demonstrate a need for undergraduate medical curricula to place a higher emphasis on simulation-based teaching as virtual clinics will continue to occupy a prominent role in medical practice.

\section{References}

1. Rose S. Medical student education in the time of COVID-19. JAMA. 2020 Mar 31;323(21):2131-2132. doi:10.1001/jama.2020.5227.

2. Dhillon J, Salimi A, ElHawary H. Impact of COVID-19 on Canadian medical education: pre-clerkship and clerkship students affected differently. J Med Educ Curric Dev. 2020 Oct 14;7:1-5. doi:10.1177/2382120520965247.

3. Al-Balas M, Al-Balas HI, Jaber HM, et al. Distance learning in clinical medical education amid COVID-19 pandemic in Jordan: current situation, challenges, and perspectives. BMC Med Educ. 2020 Oct 2;20:341. doi:10.1186/s12909-020-02257-4.

4. Barsom EZ, Feenstra TM, Bemelman WA, Bonjer JH, Schijven MP. Coping with COVID-19: scaling up virtual care to standard practice. Nat Med. 2020 Apr 14;26:632634. doi:10.1038/s41591-020-0845-0.

5. Hollander JE, Carr BG. Virtually perfect? Telemedicine for Covid-19. N Engl J Med. 2020 Apr 30;382(18):1679-1681. doi:10.1056/NEJMp2003539.

6. Calhoun KE, Yale LA, Whipple ME, Allen SM, Wood DE, Tatum RP. The impact of COVID-19 on medical student surgical education: implementing extreme pandemic 
medRxiv preprint doi: https://doi.org/10.1101/2021.08.20.21262347; this version posted August 22, 2021. The copyright holder for this preprint

response measures in a widely distributed surgical clerkship experience. Am J Surg. 2020 Apr 27;220(1):44-47. doi:10.1016/j.amjsurg.2020.04.024.

7. Srinivasan DK. Medical students' perceptions and an anatomy teacher's personal experience using an e-learning platform for tutorials during the Covid-19 crisis. Anat Sci Educ. 2020 May 6;13(3):318-319. doi:10.1002/ase.1970.

8. Al-Elq, AH. Simulation-based medical teaching and learning. Journal of Family \& Community Medicine. 2010 Jan;17(1):35-40. doi:10.4103/1319-1683.68787.

9. Morey JC, Simon R, Jay GD, et al. Error reduction and performance improvement in the emergency department through formal teamwork training: evaluation results of the MedTeams project. Health Serv Res. 2002 Dec 18;37:1553-81. doi:10.1111/14756773.01104 .

10. Woolliscroft JO, Calhoun JG, Tenhaken JD, Judge RD. Harvey: the impact of a cardiovascular teaching simulator on student skill acquisition. 1987; Med Teach. 9:53-7. doi: $10.3109 / 01421598709028980$.

11. DeVita MA, Schaefer J, Lutz J, Wang H, Dongilli T. Improving medical emergency team (MET) performance using a novel curriculum and a computerized human patient simulator. Qual Saf Health Care. 2005 Sep 29;14:326-31. doi:10.1136/qshc.2004.011148.

12. Tabatabai S. Simulations and virtual learning supporting clinical education during the COVID-19 pandemic. Advances in Medical Education and Practice. 2020 Aug 5;11:513516. doi:10.2147/AMEP.S257750.

13. Rosen K. The history of medical simulation. Journal of Critical Care. 2008 Jun 4:23(2):157-166. doi:10.1016/j.jcrc.2007.12.004.

14. Leighton K, Ravert P, Mudra V, Macintosh C. Updating the simulation effectiveness tool: item modifications and reevaluation of psychometric properties. Nursing Education Perspectives. 2015:36(5):317-323. doi:10.5480/15-1671.

15. Lilliefors HW. On the Kolmogorov-Smirnov test for normality with mean and variance unknown. Journal of the American Statistical Association. 1967:62(318):399402. doi:10.1080/01621459.1967.10482916.

16. Wilcoxon, F. Individual comparisons by ranking methods. Biometrics Bulletin. 1945 Dec;1(6):80-83. doi:10.2307/3001968. 
17. Braun V, Clarke V. Using thematic analysis in psychology. Qualitative Research in Psychology. 2006;3(2):77-101. doi:10.1191/1478088706qp063oa.

18. Takayesu JK, Farrell SE, Evans AJ, Sullivan JE, Pawlowski JB, Gordon JA. How do clinical clerkship students experience simulator-based teaching? A qualitative analysis. 2006;1(4):215-219. doi:10.1097/01.SIH.0000245787.40980.89.

19. Leo N, Andrea T, Nemat A, Victoria B. Peer-assisted learning in simulation-based medical education: a mixed-methods exploratory study. BMJ Simul Technol Enhanc Learn. 2020 Dec 16;0:1-6. doi:10.1136/bmjstel-2020-000645. 
medRxiv preprint doi: https://doi.org/10.1101/2021.08.20.21262347; this version posted August 22, 2021. The copyright holder for this preprint (which was not certified by peer review) is the author/funder, who has granted medRxiv a license to display the preprint in perpetuity.

It is made available under a CC-BY-NC-ND 4.0 International license .

Table 1: Themes Identified upon Qualitative Analysis and Sample Quotes from Participant Interviews

\begin{tabular}{|c|c|c|}
\hline Theme & $\begin{array}{c}\text { Percentage } \\
\text { of } \\
\text { Respondents } \\
\text { Who } \\
\text { Identified } \\
\text { Theme }\end{array}$ & Example Quotes \\
\hline $\begin{array}{l}\text { Collaboration } \\
\text { and } \\
\text { Communication }\end{array}$ & $9 / 12$ & $\begin{array}{l}\text { My partner and I actually live together, so we did it } \\
\text { side by side, so we could talk and make decisions } \\
\text { together. } \\
\text { I thought that [working in pairs] was really helpful } \\
\text { because we were able to bounce ideas off of each other } \\
\text { in person. } \\
\text { Our resident asked us [each] to do a brief one-liner/HPI } \\
\text { of the patient. } \\
\text { Liked working with one partner. }\end{array}$ \\
\hline $\begin{array}{l}\text { Simulation } \\
\text { Fidelity }\end{array}$ & $9 / 12$ & $\begin{array}{l}\text { The consult note was very extensive and good practice } \\
\text { for clerkship for combing through a dense file for what } \\
\text { you really need. } \\
\text { The way SP presented and weren't very sure about } \\
\text { their history and didn't give precise answers made you } \\
\text { better at probing and finding little tricks like different }\end{array}$ \\
\hline
\end{tabular}




\begin{tabular}{|c|c|c|}
\hline & & $\begin{array}{l}\text { ways to ask questions, because it's not like you'll } \\
\text { always get the perfect answer. } \\
\text { The fact that the case wasn't too complicated where I } \\
\text { felt overwhelmed about what to do: it was simple } \\
\text { enough that at our level, we should realistically know } \\
\text { what the next steps would be with relative confidence. } \\
\text { This was the best thing for the learning. }\end{array}$ \\
\hline $\begin{array}{l}\text { Virtual } \\
\text { Simulation } \\
\text { Advantages and } \\
\text { Disadvantages }\end{array}$ & $8 / 12$ & $\begin{array}{l}\text { We got some helpful tips from our resident just about } \\
\text { maneuvers, like getting a family member to do a } \\
\text { physical exam_-that sort of stuff that I didn't think of } \\
\text { before. } \\
\text { Given the sim was online, I thought it was pretty } \\
\text { realistic. I thought it was good that it included lots of } \\
\text { different aspects, like history, physical exam, and } \\
\text { investigations, which I think is pretty difficult to do so } \\
\text { I thought that was pretty good. } \\
\text { I think the method of asking for an investigation and } \\
\text { you guys posting the results was actually really smart } \\
\text { and went really well. } \\
\text { to each other it could be more awkward, but I liked that } \\
\text { partner aspect. } \\
\text { I enjoyed the "fast-forwarded" nature of the patient } \\
\text { care experience. I liked having tests available quickly. } \\
\text { can see how if it was over Zoom and you weren't next }\end{array}$ \\
\hline
\end{tabular}




\begin{tabular}{|c|c|c|}
\hline $\begin{array}{l}\text { Knowledge and } \\
\text { Skill } \\
\text { Development }\end{array}$ & $10 / 12$ & $\begin{array}{l}\text { Will remember diagnostic pathways more having } \\
\text { thought through them compared to reading in textbook. } \\
\text { Awesome that you guys didn't just give us labs, but } \\
\text { gave more prompting so that we had to decide which } \\
\text { labs are relevant. } \\
\text { We had to decide whether or not the case was urgent } \\
\text { and we also had to decide what to do for the patient as } \\
\text { they present so that was a good learning opportunity. } \\
\text { [Our evaluator] was very good about explaining the } \\
\text { details and directing us on how to effectively and } \\
\text { efficiently gain information to present to our } \\
\text { attendings. It was useful to recap why we made certain } \\
\text { decisions and understand there's a disconnect between } \\
\text { textbook presentation of a case and how someone } \\
\text { might present. } \\
\text { understanding now. }\end{array}$ \\
\hline $\begin{array}{l}\text { Suggestions for } \\
\text { Use in } \\
\text { Undergraduate } \\
\text { Medical } \\
\text { Education }\end{array}$ & $11 / 12$ & $\begin{array}{l}\text { I think if MacSim could be integrated into the program } \\
\text { somehow, it would be helpful. I think this is more } \\
\text { valuable more near the end of pre-clerkship, or even } \\
\text { having one sim at the end of each foundation, because } \\
\text { it gets you more in the clinical mindset instead of just } \\
\text { the pathophysiology and history taking. }\end{array}$ \\
\hline
\end{tabular}




\begin{tabular}{|l|l|}
\hline $\begin{array}{l}\text { It would be nice to have MacSim, especially } \\
\text { approaching clerkship. With [Transition to } \\
\text { Clerkship] electives it was variable how much } \\
\text { autonomy I had. I would say a few sessions, maybe } \\
\text { two or three, would be nice to help us practice in some } \\
\text { basic cases. I think a number of sim cases that are at } \\
\text { our level and allow us to make decisions would allow } \\
\text { us to get familiar with communicating those decisions } \\
\text { to patients outside of a formal OSCE and clinical skills } \\
\text { setting. } \\
\text { I wish we did more of this at the end of each } \\
\text { foundation as review. The trouble with tutorials is that } \\
\text { they give you the case and they're very classical } \\
\text { presentations or a very stereotypical picture, so it's } \\
\text { easy to know what the diagnosis is because they spell it } \\
\text { out for you. That's also the situation with our OSCE- } \\
\text { type scenarios. As we're starting clinical rotations or } \\
\text { pre-clerkship electives we're starting to notice } \\
\text { gathering information is very difficult - it's not always } \\
\text { spelled out for you, so I think this type of real life } \\
\text { situation is very useful. }\end{array}$ \\
\hline
\end{tabular}


medRxiv preprint doi: https://doi.org/10.1101/2021.08.20.21262347; this version posted August 22, 2021. The copyright holder for this preprint (which was not certified by peer review) is the author/funder, who has granted medRxiv a license to display the preprint in perpetuity.

It is made available under a CC-BY-NC-ND 4.0 International license .

This event was a valuable learning experience to further familiarize myself with virtual clinics.

More simulation based learning should be integrated into the pre-clerkship curriculum.

COVID-19 has significantly reduced my opportunities for learning in a clinical setting.

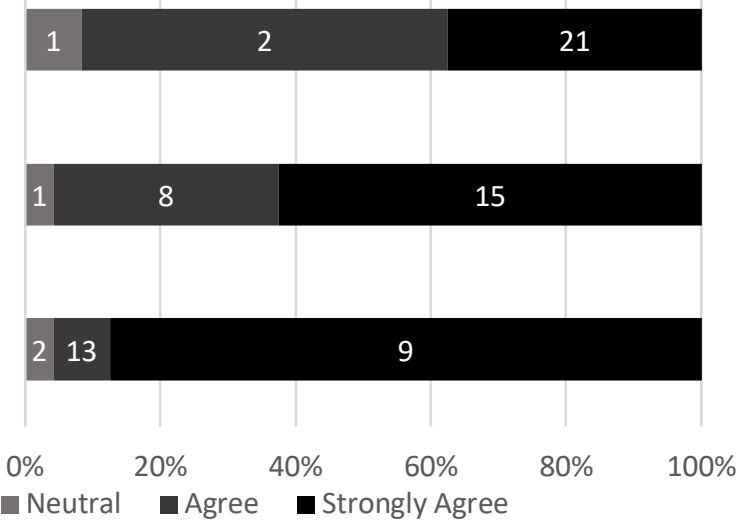

Figure 1: Likert Scale Data Obtained from the Post-Event Survey 